\title{
生态教育 自然和谐—“幼儿园课程生态化实施策略”研究
}

程敏

常州市钟楼区卜戈幼儿园

DOI:10.32629/jief.v2i7.2013

[摘 要] 生态教育是指按生态学的教育观点,克服以往的灌输式教育、园丁式教育等一系列的不足而产生的新型教育理念。目前,幼儿园的生 态教育还十分欠缺, 仅停留在生态环境的创设方面,而缺少对教育模式生态化的研究。本文结合当前现状, 对于幼儿园如何构建生态文化进行了 探讨。

[关键词] 生态教育; 幼儿园; 建设

中图分类号：G434 文献标识码：A

对于幼儿实施生态教育, 让他们从小养成良好的生态意识, 这对于 保护我们人类赖以生存的生态环境, 促进未来生态建设与发展都极具历史 意义。生态教育模式不适用传统的教育方式, 要根据生态学规律灵活对幼 儿进行教育, 因此教师队伍建设、课程设置等对于生态教育的教学效果具 有重要影响, 而这也是生态教育环境下幼儿园文化建设的核心体现。

\section{1 生态教育的内涵分析}

生态教育的内涵是按照一定的目的与计划对学生进行生态学教育, 促进学生对于生态的认识, 从而让其感受到生态环境的重要性, 养成良 好的生态意识, 进而保护生态, 促进生态建设与发展。不过传统的灌输 式生态教育并不符合生态教育的内涵特征, 尽管通过灌输式教育也能促 进学生对于生态环境的了解, 培养学生的生态意识。生态教育要摆脱传 统的灌输式、园丁式教育模式, 以一种更加符合生态规律的模式对学生 进行生态教学, 从而引导学生能够形成正确的生态伦理观与价值观, 促 进生态环境与人类社会的可持续发展。这也是实施生态教育的根本目的。 因此, 这要求幼儿园要加强文化建设, 为提升生态教育的教学效果提供 可靠保障。

\section{2 生态化教学的实践策略}

2.1 楼道植物长廊创设

基于生态学视野的幼儿园楼道植物长廊创设的首要目标就是根据幼 儿直观形象性的思维特点, 培养幼儿从小树立生态意识, 亲近大自然, 关注生态环境, 让幼儿以积极的态度参与环境创设, 在亲身体验中感受 到大自然的美, 以及成为幼儿园生态美环境创设的小主人。通过简单的 楼道创设活动, 通过观察、感知、精心护理, 门厅盆栽的不同树木, 每 种不同盆栽花卉, 微景观小河流水的景观, 感受呵护植物的乐趣, 人与 植物、自然密不可分的关系。廊道的环境的创设体现了舒适、温馨的原 则, 与生态课程相呼应的绿色植物布局的合理性, 进一步打造了 “自主 参与、勤思乐学，合作分享、彰显个性”的氛围。

\section{2 在一日生活中贯穿生态教育在幼儿的一日生活中}

教师应抓住契机, 及时对孩子进行教育, 如: 绿色出行, 教育幼儿入 园离园和父母乘坐公交车、电动车、自行车、步行, 减少坐汽车的次数, 自然环保。洗手时, 通过参观自来水厂, 观察自来水是怎样来的, 教育 孩子不要浪费水, 给他们介绍水的来源以及有些地区缺水的情况, 让幼 儿在生活中处处节约用水。午餐时通过观看土地贫㾑缺水的地方, 人们 的温饱都得不到保证, 通过观看影像资料教育孩子不挑食、不偏食、不 掉饭粒, 珍惜成人劳动成果, 从而树立孩子从小爱护自然资源的生态道 德观念, 根据园所的生态环境, 室内室外打造生态气息, 本土生态教育, 教育幼儿学会与同伴分享, 做到学会关心, 和谐相处, 做环境美化的小 主人。

\section{3 开展各项生态教育主题活动}

开展种植区、地球日、世界水日、徒步行等主题活动, 如: 世界水日 在活动前期, 老师们就组织孩子收集有关节水的图片和文字资料, 创设 环保节水的宣传版面, 提高孩子对节约用水知识的初步认识。随着活动 的不断深入，持续培养孩子从小养成爱护水源、节约用水的好习惯，老 师们开展了 “节水从我做起” 的生态教育主题活动, 向孩子们介绍世界
水日的来历, 让大家通过生动的图片和视频资料, 了解和感受淡水的珍 贵, 并带领幼儿实地参观自来水厂, 让幼儿知道现在城市的饮用水是经 过自来水厂加工消毒后变成的, 教师组织幼儿来到社区通过发放节水标 志, 呼吁大家一起来节约用水, 懂得节约用水从我做起, 愿意向周围的 人宣传节水的重要性。

\section{3 探索生态课程}

3.1 课程目标生态化

在 “保护天性、尊重个性, 让生命自然绽放” 的理念指引下, 通过 课程的推进, 让幼儿透过知识学习、实践活动、环保行动、节日宣传等 形式了解人与自然的关系, 形成重视生态环境的氛围, 让每个幼儿在耳 濡目染中树立生态意识。

3.2 课程内容生态化

我园结合《指南) 探索构建生态教育课程体系, 包含环境主题课程、 区域游戏课程、户外游戏课程、实践活动课程等。1. 环境主题课程凸显 一个 “精” 字我们根据 “地球日” “世界环境日” “世界水日” “世界无烟 日” “植树节” 等节日设定 “地球” “动物” “植物” “水 “绿化 “垃圾” “食物” “季节” 等主题活动, 帮助幼儿获得人类与环境、动植物与环境 的基本知识, 增强环保意识, 并通过组织健康徒步行、社区环保知识宣 传等活动, 实现教师带动孩子, 孩子带动家庭, 家庭辐射社区的连动作 用。每次主题课程我们都用心准备、精心设计、细心梳理, 才有了精彩 纷呈的活动和效果。2. 区域游戏课程凸显一个 “趣” 字兴趣是最好的老 师，孩子的兴趣点在哪，我们的课程就在哪，通过师资培训，老师们将 《指南》的目标要求熟记于心, 同时根据尊重个性的理念指引, 结合本年 段幼儿的发展水平，区域做到班班有特色，班班有亮点，如小班组的生 活操作区、娃娃家: 中班组的建构、益智; 大班组的科学、表演可谓丰富 多彩、妙趣横生。多姿多彩的活动让幼儿乐此不疲、流连忘返。同时创 意美工室、奥尔夫音乐教室、陶工坊、木工坊、图书室、科学室和沙画 功能室就像彩虹的七种颜色为幼儿的游戏增添了色彩。3. 户外游戏课程 凸显一个 “活” 字在活动场地全面规划中, 既设置了体育动作技能练习 区，也有自主游戏区。如：“阳光沙滩” “野趣运动区” “神工巧匠” “智 勇攀岩” “勇往直前” “探险密道” “欢乐戏水” 等,

幼儿生态教育对学生长远的发展和素质的提高都是极其重要的。那 么作为幼儿教师一定要主动打破传统陈旧教育理念的束缚, 主动的寻求 教育创新, 为幼儿创造良好的学习模式环境与成长的氛围, 让孩子在良 好的教育环境和方法中茁壮的成长, 因此我们担负着巨大的责任。

\section{[参考文献]}

[1]王倩.幼儿园科学教育活动的设计与指导研究 [J]. 当代家庭教 育,2020(19):55-56.

[2]石娟. 幼儿园开展科学教育的方法 [J]. 当代家庭教 育,2020(23):47-48.

[3]巩丽娟.论幼儿园科学教育生活化 [A].教育部基础教育课程改革 研究中心.2020 年 “教育教学创新研究” 高峰论坛论文集[C].教育部基础 教育课程改革研究中心: 教育部基础教育课程改革研究中心,2020:1. 